\title{
La ironía del chiste
}

\section{María Pérez Yglesias \\ Universidad de Costa Rica}

\section{La práctica del chiste en la mira sociocrítica}

— ¿Vos sabés por qué a Calderón le dieron el primer premio en agricultura?

-No, ¿por qué?

-Y diay, muchacha, porque nos tiene "sembrados" a todos los ticos y por su extraordinaria cosecha de "chiles".

La Sociocrítica nace con un objeto de estudio concreto, la literatura; y un objetivo preciso, su función socializadora. El carácter materialista de la propuesta, su fundamentación ideológica institucional y su interés por el sujeto colectivo provocan que, poco tiempo después de sentar las bases teórico-metodológicas, los investigadores amplíen el campo de estudio y se ocupen de prácticas significantes (productoras de sentido social) diversas:

Si bien uno de sus mayores intereses ha sido el discurso literario, la versatilidad de su enfoque teórico hace que en la actualidad abarque el estudio crítico e interpretativo de otras formas textuales y de otras manifestaciones artísticas como la pintura, la música, el cine; teniendo siempre como base la relación dialéctica texto-sociedad ${ }^{1}$.

1. Amalia Chaverri y Rita Porras, «A propósito de la sociocrítica». Suplemento Áncora, La Nación (21 de noviembre de 1993) 2-D. 
Como planteamiento semiótico, la Sociocrítica se ocupa de producciones verbales y no verbales, trabaja los diversos discursos de la sociedad, que se construyen mediante distintas materialidades (códigos), y se preocupa no sólo por su interrelación sino por la transposición de un lenguaje a otro. Son, por ejemplo, sumamente interesantes los trabajos sobre literatura y cine.

La Sociocrítica es transdisciplinaria como construcción teórica y como posibilidad de acercamiento a distintas prácticas culturales, manifiestas en discursos que dan cuenta de la socialidad. Por lo tanto, su campo de acción ha debido abrirse y contemplar textos más allá de lo literario y artístico, textos que se salen del área definida estrictamente como "cultural" (artes y letras) y se insertan, sobre todo, en el espacio de las llamadas "ciencias sociales", es decir, la historia, la política y la comunicación. Esta apertura hace posible el acercamiento a una práctica significante como el chiste.

Los espacios de las artes y la comunicación resultan, entonces, tentadores para el análisis sociocrítico, basado en el instrumental semiótico y en una teoría de la sociedad que le permite explicar el texto en su significación implícita, en sus pre-supuestos, en sus matrices preconstruidas. Más que de texto habría que hablar de socio-texto, donde "la ideología es una función productora y un principio de estructuración"2.

Si se hace referencia a un socio-texto puede hablarse de sociohumor o de socio-chiste, cuyo mecanismo ideológico estructurante es la ironía, tanto en su relación intertextual (ironía generalizada o paródica), intratextual (ironía retórica) o extratextual (ironía satírica); tanto en su posibilidad semántica (antífrasis) como pragmática (intención evaluativa).

2. María Amoretti, Introducción al sociotexto. A propósito de Cachaza (San José: Editorial de la Uiversidad de Costa Rica: 1989) 33. 


\section{El chiste entre la continuidad y la ruptura}

-Dicen que a Calderón le dieron el Premio Nobel de Literatura.

— ¡No puede ser!, ¿de veras?

- ¡Claro! ¿No te diste cuenta que logró hacer más Miserables que Víctor Hugo, y ya superó El idiota de Dostoievski?

Como discurso (transformaciones intertextuales paradigmáticas) y como texto (transformaciones intratextuales sintagmáticas), el chiste se plantea como uno de los mecanismos de socialidad más evidentes: relaciones con el otro, a partir del lenguaje en diálogo.

El texto (chiste particular) se nutre de las posibilidades discursivas (discursos sociales diferentes) y las redistribuye en un orden combinatorio propio. El chiste constituye, en sí mismo, un espacio dialógico, es decir, una "zona de conflicto en la que convergen huellas ideológicas diferentes, pertenecientes a discursos opuestos o contradictorios" ${ }^{3}$.

En el chiste, aun más que en otras prácticas culturales, se evidencia la importancia de las condiciones en que se emite y se recibe y su estructuración (matrices básicas), siempre cambiante en la expresión concreta. Interesan el proceso de producción y el de consumo condicionados por un tiempo, un espacio, un grupo social, una coyuntura específica, una ideología, una institucionalización particular. En el caso de este trabajo se escogen chistes del expresidente de Costa Rica, Rafael Ángel Calderón Fournier (Junior Calderón, 1990-1994).

El chiste, a través del humor y la ironía, provoca su estudio como producción significante, que ocupa un lugar en la historia y que posee un valor social. Critica la autoridad, marca y/o rompe los tabúes, los estereotipos y prejuicios y muestra, claramente, los conflictos sociales, ya

3. María Amoretti, Diccionario de términos asociados en teoría literaria (San José: Editorial de la Universidad de Costa Rica, 1993) 46-47. 
sea que haga referencia a la política, la religión, el sexo o la etnia. Actúa como mediación, como filtro que de una u otra manera, transforma la realidad de que parte el texto.

Es una práctica significante que marca y remarca la "diferencia" (social, religiosa, de género, política, racial), burlándose de ella, cuestionándola y concretándola, de nuevo, en la propuesta tradicional. Mostrándose, a veces, profundamente revolucionario, el chiste reproduce el sistema, la ideología dominante, pero la hace susceptible de "sospecha", le otorga un sentido doble, un posible diferente.

\section{El chiste siempre compara: entre la crítica y la catarsis}

— ¿Vos sabés en qué se parece Calderón a las medias?

-No, ¿en qué?

—Diay, en que sólo sirven para "meter las patas".

- ¿Y sabés por qué prohibió la pasta dental para niños?

— ¿La prohibió?

-Claro, no ves que cada vez que abría el botiquín del baño, el tubo de pasta, le decía: "¡Colgate, Junior!"

La ironía es el arma discursiva más importante para combatir el poder. El llamado "choteo", la "serruchada o bajada de piso", adquiere formas diversas — una de las más importantes es el chiste-y le sirve a los grupos populares, a los oponentes políticos, religiosos, étnicos, etarios (edad) o sexuales para contrarrestar, debilitar o destruir el poder, la autoridad, la preponderancia y la prepotencia. Pero sirve también para mostrar las angustias, los miedos, la curiosidad ante la diferencia, ante el "otro". Muestra los mitos, estereotipos, prejuicios y tabús de una sociedad y, burlándose de un "acto", "característica" o "coyuntura", los relativiza y, al mismo tiempo, los reproduce y consolida.

Acto ilocutorio, con efecto ciertas veces crítico y transformativo, otras veces catártico y reproductor, el chiste y lo cómico tienen 
mucho de liberador, suponen, para Freud, una ganancia de placer que puede ponerse al servicio de la agresión ${ }^{4}$.

La ironía y el humor (cómico) se convierten en las piedras angulares de construcción de esa práctica (trabajo) significante (con el sentido) tan popular y lapidaria que es el chiste. Este trabaja un significado particular, pero privilegia el significante. Está construido, siempre, sobre la comparación:

a. por contraste: conduce a una toma de partido, a una valoración: autoridades/subordinados, judio/católico, hombre/mujer;

b. por contradicción: un elemento contradice a otro elemento. Lo que se dice de la persona no corresponde a su rol social, el gesto o la palabra, la "causa" produce un "efecto" inesperado, sorpresivo, incluso, incoherente;

c. por contrariedad (contrarios): un elemento es contrario al otro sin que implique, necesariamente, una valoración positiva o negativa de los extremos.

Estos tres tipos de comparación (de los cuales los más frecuentes son la contradicción y el contraste) son factibles en la relación entre:

- $\quad$ la realidad (contexto) y la anécdota-chiste (el texto);

- $\quad$ elementos dentro del mismo chiste (intratexto);

- $\quad$ elementos del chiste, los mitos que lo respaldan (génesis) y un ideal por alcanzar (lo que debería ser la realidad, el deseo, la utopía, el sueño...).

La ironía surge, entonces, por contraste, contradicción o contrariedad entre los presupuestos y el chiste; entre personajes, acciones, gestos, referencias dentro del chiste mismo y la realidad que se conoce, entre lo que plantea el chiste y lo que "debería ser" esa realidad. Este

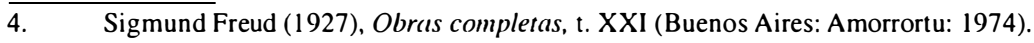


juego intertextual (contexto/texto, textos o voces en el mismo texto) se manifiesta al menos como doble y, ahí, surge la ironía con su dosis de humor y de reflexión.

\section{La ironía humorística del chiste: ¿filtro de producción y lectura de la realidad o juego retórico?}

—Adiviná cuál es el libro preferido de Junior Calderón...

—Pues, ¿cuál va a ser?: El Lazarillo de Torpes. ¡Imaginate que apenas hace un año que lo empezó y ya va por la página veinte!...

Existen, varios tipos de ironía; o, mejor dicho, esta se puede clasificar desde diversos puntos de vista:

Ironía referencial (texto-chiste/contexto-realidad), y la ironía verbal (juego irónico entre los diferentes elementos del chiste tomado como discurso, ya sean palabras, acciones o personajes) ${ }^{5}$.

Ironía retórica o ironía generalizada táctica ${ }^{6}$

En la primera, la ambigüedad planteada se resuelve, es el arte de la persuasión, puede ser muy violenta y se acerca a la sátira; en el segundo caso, se mantiene el malentendido, el doble. Es menos agresiva, pero más destructiva. Se acerca a la parodia: ser y no ser al mismo tiempo.

Ironía de uso e ironía de intervención ${ }^{7}$

La de uso es la que se encuentra ya en estereotipos sociales, la segunda es más o menos inédita.

Ironía verbal (antifrase) e ironía textual, de género (ironía paródica e ironía satírica) ${ }^{8}$.

La parodia (trasposición de textos, marca de la diferencia,

5. C. Kerbat Orecchioni y otros, L'ironie (Lyon: Presses Universitaires de Lyon: 1978) 17.

6. Kerbat Orecchioni y otros, 17.

7. Kerbat Orecchioni y otros, 22 y ss.

8. Linda Hutcheon, «Ironie, satire et parodie, Un aproche pragmatique de l'ironie», Poétique (1981) 140-155. 
crítica y lúdica, agresiva y seductora) y la sátira con su intento crítico y transformador de las costumbres morales y sociales, se nutren de la ironía como recurso retórico.

Ironía semántica (verbal) e ironía pragmática (relación comunicativa). La semántica plantea la oposición entre "eso que uno dice y eso que uno quiere hacer entender"; esconde una censura burlesca. La pragmática se concentra en el efecto de los signos. Esta relación entre la intencionalidad evaluativa de un autor codificador (manipulador) y un receptor (decodificador) con una determinada competencia, hace que el acto de lectura vaya más allá del texto. La función pragmática consiste en una señal de evaluación casi siempre peyorativa. De esta manera, la ironía, por una parte establece un contraste y, por otra, evalúa 9 . La ironía en el chiste puede presentarse como ${ }^{10}$ :

a. una manera de burlarse de alguien o de algo. Implica un ataque, denuncia o agresión contra un objeto/sujeto concreto. Cumple una función desvalorizante y está al servicio del convencimiento;

b. un procedimiento lingüístico de antífrasis. Expresa lo contrario de lo que se quiere decir. Se descubre por el gesto, el tono, los silencios, entre otras manifestaciones. No es una mentira y no es del espacio de la "verdad" (ético), sino del de la verosimilitud (creíble, no real);

c. un acto de lenguaje no directo (elocución). La ambigüedad es lo central. El lector duda entre dos lecturas: el lenguaje irónico, paródico, siempre es relativo; "repudia su rol de representación (provocando la risa) pero no llega a desprenderse del todo de él" ${ }^{\prime 1}$. A un significante responden dos significados (literalintencional), se debe atravesar lo retórico del signo y alcanzar un nivel connotativo, el nivel de lo implícito, de los preconstruidos;

\footnotetext{
9. Hutcheon, 46.

10. María Pérez Yglesias, «Lenguaje popular e ironía en la producción de Hugo Díaz Jiménez», Kánina, VII (1983) 158-159.

11. Julia Kristeva, Le texte du roman (La Haya, Mouton: 1970) 161.
} 
d. una actitud ante la realidad. Trata de una ironía retórica que se da en el juego de las palabras, en las contradicciones de la vida, en lo que implique un desequilibrio en la norma, un tono burlesco y crítico.

Como el objetivo de la ironía no es dar una idea de verdad, marca las huellas que permiten descubrirla. Para Freud, por ejemplo, la ironía retórica trata de evitar al otro caer en la contradicción y se marca en "las inflexiones de la voz, los gestos significativos, algunos artificios de estilo en la narración escrita"12.

Los silencios, lo no dicho, lo connotado y presupuesto, el uso de otros códigos, como el gestual o el cinético, permiten el juego entre lo implícito y lo explícito y favorecen el valor significante. El chiste media, como discurso, entre el poder y la subordinación y rechaza el dogma y la "verdad" para sumergirse en el espacio de la ambigüedad $y$, como retórica, trata de resolverla. Al mezclar el humor con la reflexión, asume un rol "desenmascarador", crítico de la realidad, aun cuando a veces solo parezca reproducirla.

\section{El chiste como drama cotidiano carnavalesco: las matrices de significación}

Dicen que Calderón Fournier ama tanto a los pobres... que en dos años logró multiplicarlos.

Todos los chistes se insertan en un sentido irónico general (paródico, satírico) y la ambigüedad siempre está presente. La ironía del chiste exige al escucha (lector) tomar una parte activa suplementaria, no sólo en el proceso de decodificación sino en su propuesta personal como contador. La pragmática, en este caso, es tan o más importante, que la semántica misma.

$\overline{12 . \quad \text { Freud, } 267 .}$ 
Ese proceso de "lectura-escritura" o, más bien, "escucha-habla" se evidencia con mucha más claridad en el chiste, que se constituye en "el pequeño teatro de la calle, un teatro popular y dinámico, humorístico y carnavalesco"13.

Como "diversión pública" y "privada" a la vez, el chiste es representado por actores múltiples y en diversos espacios escénicos. Los actores pueden resultar extraordinarios y, de acuerdo con el público y la circunstancia, se permiten la libertad de adaptar el libreto.

Cada chiste le pertenece a la colectividad (en el espacio carnavalesco todos son actores y todos viven la representación), asume las voces populares, en sus más variadas posibilidades, y se construye como cortos rituales, siempre recomenzados y siempre transformadores en el acto de lenguaje. Exige participación activa y, aunque a veces se reciba con amargura, da lugar a lo cómico.

El chiste es una formación discursiva que responde a diversas matrices que se relacionan con la costumbre y actúan como ayudamemoria. Las variantes que sufren no afectan profundamente la organización primaria y coinciden con parte de la tradición popular.

El chiste se elabora, entonces, a partir de tres fórmulas básicas con sus variantes: la adivinanza, el chisme y el relato.

El trabajo significante del chiste se construye alrededor de tres grandes núcleos: a) la entonación, el gesto y el movimiento; b) la composición y las pausas; y c) los elementos de desequilibrio (los nombres, los tipos de discurso, las manifestaciones populares y otros juegos con el lenguaje). Esas tres variables se combinan entre sí y producen un efecto en el receptor, quien, convertido las más de las veces en actor, retoma el ritual.

El chiste-adivinanza posee un carácter lúdico y pretende desentrañar "un misterio", que no lo es. La estrategia de la pregunta estimula la participación y aporta diversas posibilidades al diálogo. Sus fórmulas fundamentales son "el misterio del telón" y la pregunta directa.

1.3. Marria Péres Y'glesials, "La escenal del chiste: el pequeño teatro de ba calle». Escéna. XIII-XIV. $28-29(1(5) 2) 32$. 
El telón devela escenas de significación múltiple, actúa como una máscara que se descubre y da paso a representaciones también enmascaradas. La respuesta del escucha siempre lo implica en los presupuestos y en el contexto del escenario. Los "actores del chiste" casi nunca reciben la palabra y sólo forman parte del juego como sujetos de burla, crítica o agresión, de parte del contador y del receptor. Pueden ser uno, dos o tres actos y, de lo que se trata es de averiguar el nombre de la obra:

Se abre el telón y aparece un tren con las altas autoridades del gobierno; se cierra el telón. ¿Cómo se llama la obra?: Un tren de (irresponsables, ignorantes, hijue...).

Las fórmulas populares de la adivinanza varían, pero se presentan siempre como preguntas, que exigen una respuesta del interlocutor, estimulan nuevas preguntas y generan nuevos chistes: ¿usted sabe cn qué se parece...?, ¿por qué le dicen...?, ¿cómo se llama...?, ¿qué resulta si...?

¿En qué se parece Costa Rica a una mujer negra embarazada?/ En que las dos tienen "un negro porvenir".

¿Te imaginás qué resultaría de la mezcla de Calderón con un pez?/ No, ¿qué?/ Pues, ¡un caballito de mar, por supuesto!

¿En qué se parece Junior a Pelé?/ No sé./ ¡Pues en el nombre, maje!/ ¿Y por qué en el nombre?/ Porque antes Pelé se llamaba Nelson Arantes do Nascimento; y Junior es "necio ignorante de nacimiento", o "menso desdiantes del nacimiento".

¿Vos sabés por qué a Calderón le dicen el Chavo de 24?/ No./ Porque es tres veces más bruto (ingenuo, tonto, feo...) que el Chavo del 8. 
La segunda matriz significante parte del rumor: no se explicitan las fuentes de información y el contador transmite "lo que le contaron". La fórmula permite los excesos (incluso insultos) sin responsabilidad de autoría; y cada una de las personas que propagan el chisme se considera con derecho propio para modificarlo a su antojo. Se marca claramente la cadena comunicativa: alguien afirma algo a otro que lo repite...

Dicen que Gloria, Rafael Ángel y Rodolfo Méndez fueron a darle el pésame a la viuda del embajador de Japón, que murió en un accidente de avioneta. Gloria, se presenta ante la señora y la abraza:- I am sorry. Seguidamente Méndez Mata le dijo:-Me too. Y Calderón, que se había quedado de último para no meter la pata, se acerca y dice compungido: - Me, three!

Dicen que al Gobierno de Calderón le dicen SIDA 1990./ —iNo puede ser!, ¿y por qué?/ —Porque tiene al país "Sin Inteligencia Después de Abril 1990".

Los más difíciles de memorizar son los que construyen un relato. Parten de algunos elementos del contexto (personajes, hechos ocurridos), para jugar con la "verosimilitud de lo inverosímil". La risa es provocada por la intertextualidad, el juego de las palabras, lo absurdo de la situación, el doble sentido, la mostración de un tabú, un prejuicio o un estereotipo. El narrador, como en los otros casos, es el que conduce el hilo y "presta" la palabra a los actores, para lograr una doble ironía:

Gorbachev, Bush y Junior son hechos prisioneros cerca de Basora, en Irak, y condenados a muerte. El fusilamiento se va a realizar en tres días consecutivos. El líder soviético aprovecha el carácter supersticioso de los irakíes, y poniéndose en trance grita: ¡TERREMOTOOOO!!! Todos corren asustados y él se salva.

Al día siguiente, y cuando le corresponde el turno a Bush, este grita: ¡MAREMOTOOO!!!, y se salva. 
Rafael Ángel piensa durante toda la noche cuál podría ser su truco y, al fin, cuando está frente al pelotón de fusilamiento decide gritar: ¡FUEEGOOO!!!

En una celebración del día de las madres, se reúnen las madres de Bush, la de Gorbachev, la de Calderón Fournier; y un grupo de periodistas las entrevista:

- Señora Bush, ¿podría usted decirnos con qué tipo de leche crio usted a su hijo?

-Con leche de búfala, por supuesto. Por eso las decisiones de mi hijo son fuertes, determinantes...

- ¿Y usted, señora Gorbachev?

- A Mijail yo le di leche de foca, de ahí que sus ideas sean tan frías, tan calculadoras, tan claras...

-Doña Rosario, ¿y usted?

-Bueno, como nosotros somos gente más pudiente, no necesitamos alimentar a Junior con leche de animales salvajes. Yo lo alimenté con leche de magnesia, y seguro por eso es que se está "paseando (cuiteando, c...) en Costa Rica".

En este pequeño teatro de la calle, el lenguaje verbal es básico, pero su combinación con otros códigos adquiere una "sobredosis de sentido". En algunos casos, los gestos o los sonidos dan la clave del sentido y provocan la risa; esta situación dificulta mucho más la transcripción y obliga, como en el teatro, a utilizar acotaciones. El chiste es oral y mimético, por esta razón la escritura mata parte de su enorme seducción. 


\section{El chiste en síntesis}

-Doncito, doncito, ¿le limpio los zapatos, y le cuento un chiste del Presidente?

-Pero, mijito, si yo soy Rafael Ángel Calderón Fournier.

- No importa, doncito, le limpio los zapatos y le cuento el chile bieeeen despacito para que lo entienda, ¿sí?

Una rápida propuesta de lectura-escritura amerita sintetizar, en este momento, los rasgos más relevantes de esa práctica humorística particular. El chiste, aun considerando sus diferencias, se puede considerar como:

a. anónimo: no existe una autoría concreta; todos son potenciales "hacedores" y "transformadores" de chistes;

b. oral: se transmite en el discurso y, al no formar parte de la escritura, sufre continuas modificaciones. Cuando se pasa a la escritura verbal o al dibujo - caricatura, historieta, chiste dibujado- conserva una serie de rasgos que marcan la voz;

c. humorístico: lo racional se quiebra con la risa, la lógica tradicional se irrespeta y lo pulsional, lo semiótico, atraviesa el sistema, mostrando el trabajo de producción de sentido;

d. actual: siempre se refiere a un personaje, una acción, un fenómeno de actualidad; un mito, un estereotipo, un tabú social, aun cuando se utilicen formas tradicionales, existe una actualización;

e. popular: usa recursos tradicionales del habla popular, el contador y el escucha no necesitan ser ni siquiera alfabetos, por lo tanto, no se trata de una práctica significante restringida;

f. crítico: siempre procura evidenciar un problema, un defecto, un error. Además de estimular la risa, induce a la reflexión;

g. carnavalesco: el emisor y el escucha participan activa y simultáneamente;

h. ambiguo: aun en los casos en que se resuelve la ambigüedad, siempre existe un doble, una duda; 
i. caricaturesco: se construye como una exageración de rasgos, defectos, debilidades, acciones;

j. valorativo: juega con los valores y disvalores de la sociedad; con los estereotipos y prejuicios;

k. clasificable: la primera división se hace entre "chiste" y "chile", este por su carácter sexual y "vulgar"; además, se califica, según su predominio, como chiste político, racial, religioso, sexual; según el tipo de humor, como negro, satírico, paródico; según el destinatario, como infantil, intelectual, popular, femenino;

1. espacio semántico y pragmático, es decir, contraste entre un significante y dos significados y acto de evaluación (relación comunicativa: contador-escucha);

m. pertenece a los géneros paródico (intertextual) y satírico (extratextual) en sus múltiples variedades y es también un juego lingüístico (intratextual);

n. práctica significante de ruptura: aun cuando aparentemente reproduzca el sistema, su carácter ambiguo, lúdico, caricaturesco lo hace un "trabajo con el sentido" de ruptura. Lo semiótico, lo emotivo, lo pulsional, el quiebre, la fisura, siempre están presentes.

El chiste, como todas las prácticas significantes o producciones de sentido(s), sólo existe en su actualización (pragmática, acto intencional y evaluativo). Únicamente se encuentra en ese espacio comunicativo donde se ponen en juego los pre-supuestos (preconstrucciones) del paradigma mítico-histórico-cultural y se construyen sentidos suplementarios en la sintagmática de la producción, sobre un juego semántico.

El chiste evidencia con fuerza y claridad el proceso de producción en la producción misma. Entre la tradición y la ruptura; entre lo dicho y lo supuesto o sugerido; entre el contraste y la evaluación; en el espacio del doble, del signo y del texto, de lo intra, inter y extratextual, el chiste representa esa eterna dualidad de las sociedades y los seres humanos que, queriendo transformar, defienden lo establecido. 
El humor y la ironía son las estrategias de ese juego siempre recomenzado de rituales, de parodias y sátiras, que explotan con la risa e inducen a la toma de conciencia y a la reflexión. 